\title{
Research on Pre-Litigation Procedure of Administrative Public Interest Litigation Initiated by the Prosecutorial Organization*
}

\author{
Yifan Shi \\ School of Public Affairs and Administration \\ University of Electronic Science and Technology of China \\ Chengdu, China 611731
}

\begin{abstract}
In the process of prosecuting public interest litigation, a pre-litigation procedure has been taken as an important system design as the litigation procedure. The twoyear pilot result indicates that most of the administrative public interest disputes can be solved through the pre-litigation procedure. On one hand, the pre-litigation procedure can urge the administrative department to perform their duties and case diversion in order to improve the judicial efficiency; on the other hand, it helps coordinate the relationship among various organizations. However during the practice, there are still a variety of problems existing in the pre-litigation procedure. Thus it is necessary to analyze and discuss the operational procedures of the pre litigation procedure, the judgment of the administrative organization's in performing their duties, and the investigation and evidence collection such subjects, so as to guide the judicial practice.
\end{abstract}

Keywords-administrative public interest litigation; prelitigation procedure; operational situation

\section{INTRODUCTION}

It has been three years since the public interest litigation started as a pilot till now. During this trial period, the prosecutorial organization has played a big role in bringing the administrative public interest litigation system in the practice, which not only urged the closing of a big number of highly polluted enterprises, saved a large area of ecological public forest, but also recovered big amount of illegally occupied state-owned land and state-owned property with a remarkable result. However, according to the feedbacks of the front-line investigators, there are still many problems existing in the operation of the administrative public interest litigation system to be solved.

*Fund: Financed by National Social Science Fund of China (Project Number: 18CFX032).

\author{
Xian $\mathrm{Fu}$ \\ School of Public Affairs and Administration \\ University of Electronic Science and Technology of China \\ Chengdu, China 611731
}

\section{The VAlue of Pre-Litigation Procedure}

The original intention of the pre-litigation procedure is to restrict the legal supervision power of the prosecutorial organization. This restriction of the procedure is made due to the prosecutorial power and administrative power belong to different categories of national power and perform their functions and duties in their respective fields: the prosecutorial organization as the legal supervision institution, who supervises the trial activities of the court and whether the administrative acts of the administrative institution are legal; the administrative organization exerts the administrative management power in the professional fields of each department. In the activities of administrative public interest litigation, the prosecutorial organization needs to urge the administrative institution to perform its duties according to the law or to correct the inappropriate administrative acts. But before bringing a lawsuit, it must start with the pre-litigation procedure. In fact, the pre-litigation procedure is the result of organizational game. Theoretically, why should a pre-litigation procedure be set up?

\section{A. Urging the Administrative Organizations to Perform Their Functions or Correcting Illegal Administrative Acts in Accordance with the Law}

Compared with the prosecutorial organizations, administrative organizations are more professional and technical in the protection of public interests, and have more advantages, especially in the fields of ecological environment and resource protection, food and drug safety, administrative organizations are more familiar and professional, plus they have more specialized personnel engaged in the relevant work. On the contrary, prosecutors with law as their main knowledge background may lack knowledge and technology in the relevant fields. Therefore, through the pre-litigation procedure, the administrative organizations can auto-correct the errors by taking advantages of the administrative organizations in order to make the correction more thoroughly. In addition, no matter 
in the fields of economy, culture, education, environment, medical treatment and so on, it can not be separated from the administrative management with a wide range and complexity. Sometimes, the staff of administrative organizations can not detect their administrative acts or misbehaviors by themselves. The pre-litigation procedure kindly "reminds" the administrative organizations to pay attention to its illegal behaviors by sending prosecutorial suggestions with a purpose of making them realize and correct their errors, instead of prosecuting the administrative organizations through a restrict litigation procedure right away, which is more favorable for the administrative organizations to accept the legal supervision and reduce their resistance [1]. In addition, the highly polluted enterprises are often the "big tax payers" in local areas to whom the administrative organizations may turn a blind eye when the public interests are damaged by taking the consideration of local economic development or driven by departmental interests. In this case, only through the social supervision of individuals or relevant organizations may not be enough to effectively restrain the administrative organizations, while through the pre litigation procedure, the prosecutorial organizations can not only remind them to exert their powers according to the law, but have the compulsory means of bringing a lawsuit if they fail to perform their duties, which will give them pressures to correct their illegal behaviors.

\section{B. Realizing the Case Diversion and Improving the Judicial Efficiency}

Case diversion often occurs in the field of civil litigation, which deals with different types of civil cases through different dispute resolution procedures (such as simple procedures, conciliation procedures, etc.), so that the limited trial resources can be maximized. From the perspective of practice, the majority of administrative public interest litigation cases have been solved in the stage of the pre-litigation procedure, only a small number of cases have finally entered the litigation process. Through the form of prosecutorial suggestions, the pre-litigation procedure can achieve the goal of correcting the illegal administrative acts with high efficiency and low cost, and the infringed public interests can also be saved within a short period. In addition, the civil and administrative departments of the prosecutorial organizations are facing a dilemma of more cases but with fewer people. On one hand, the pre-litigation procedure provides the prosecutorial organizations with a "calm period", on the other hand, it provides them with a "correction period" to reduce the frequencies of administrative public interest litigation as many as possible [2] so that the courts can focus their limited time and energy on a small amount of cases of public interest litigation to reduce the trial pressures as much as possible, and improve the trial efficiency. Justice as the last defensive line to safeguard fairness and justice should be applied after exhausting all the other remedy measures, rather than bringing a lawsuit at any time [3].

\section{Promoting the Communication and Coordination Among Prosecutorial, Administrative and Judicial Organizations}

The setup of a pre-litigation procedure requires the prosecutorial organization to communicate and coordinate with the administrative organization before initiating the administrative public interest litigation. In the area of social public interests, there is the possibility that the administrative organization may fail or "Regulatory Capture ", while the prelitigation procedure has the institutional advantage in dealing with such problems. However, as mentioned above, the administrative organization is more representable for the public interest. The most effective way to protect the public interest is the administrative law enforcement, and the prosecutorial power actually only plays a supplementary role. The judicial organization should always keep a neutral attitude and play its restrictive function when the administrative organization improperly exerts its power. This kind of characteristic and capability of judicature is not only the objective requirement of judicature itself, but also a necessary system design for political reign and an empirical political technology [4]. The setup of pre-litigation procedure can reasonably divide the power boundary among the three organizations, not only promoting the prosecutorial organizations to effectively exert the legal supervision power, but also ensuring the prosecutorial power not to interfere too much in exerting administrative power.

From the above analysis, it can be seen the pre-litigation procedure is obviously a system design of "killing two birds with one stone": it can urge the administrative organizations to perform their duties in correspondence with the law and take the initiative to correct mistakes as well as can save judicial resources and reflect the modesty of judicial power.

\section{OPERATIONAL SituAtion AND ANALYSIS OF THE PRE- LITIGATION PROCEDURE}

After the "pilot project" was published, all regions have carried out the pilot work of public interest litigation in full speed. The results of the two-year pilot show that the prelitigation procedure plays an irreplaceably important role and have made remarkable achievements.

After an half year of the pilot project, prosecutorial organizations found 501 clues of public interest litigation cases, and the amount of clues for the administrative public interest litigation accounted for about $76.4 \%$, while the number of cases of illegal administrative acts corrected by the administrative organizations during the stage of the prelitigation procedure was 118 (excluding cases replied less than one month) and $79.7 \%$ of cases could have been resolved in the stage of pre-litigation procedure [5].

After one year of the pilot project, 1,942 public interest litigation clues have been found by the prosecutorial organizations one after another. Compared with the pilot project of half a year ago, the number of case clues has 
increased nearly three times. In the administrative public interest litigation, which accounts for $53.9 \%$ of the total cases, 814 cases have been seriously taken by the administrative organizations after having received the prosecutorial suggestions, and they have taken the initiatives to perform their duties and recovered the damaged public interests, which is $88.86 \%$ of the total number of pre-litigation procedures [6].

When the pilot project has reached one year and half, the prosecutorial organizations have handled a total of 4,378 cases of public interest litigation, an increase of nearly 1.25 times compared with 1,942 cases in first year of the pilot, with a moderate growth rate, but still relatively fast. There are 3,883 cases handled through the pre-litigation procedures, of which 3,763 are administrative public interest litigation. The distribution of case clues in the two types of litigation is extremely uneven, and the proportion of administrative public interest litigation cases accounts for more than $95 \%$ in the pilot period of one and a half years. Up to $75.4 \%$ of cases have already been fulfilled in the pre-litigation procedure stage. It can be said that the setup of pre-litigation procedure can resolve most cases before entering the stage of litigation procedure [7].

At the end of the pilot project, 9,053 public interest litigation cases were handled by the prosecutorial organizations according to the law, and $84.8 \%$ of administrative public interest litigation cases had clues, which are 7,676 cases. Among them, $77.14 \%$ of the administrative organizations took the initiatives to perform their duties and recover the damaged public interests [8].

After the completion of the pilot project, the number of cases handled by the prosecutorial organizations still increased rapidly. According to the statistics, in 2018, the prosecution handled a total of 113,160 cases of public interest litigation, including 4,393 civil public interest litigation and 108,767 administrative public interest litigation. In administrative public interest litigation cases, the prosecutorial organizations have issued 101,254 prosecutorial suggestions to the administrative organizations, $97.2 \%$ of which have been adopted by the administrative organizations [9]. (See "Table I")

TABLE I. Situation of Handling Public Interest Litigation CASES By Prosecutorial Organizations in Pilot AREAS

\begin{tabular}{|l|l|l|l|l|l|l|}
\hline Deadline & $\begin{array}{c}\text { Total } \\
\text { number of } \\
\text { cases (per } \\
\text { case) }\end{array}$ & $\begin{array}{c}\text { Increased } \\
\text { percentage } \\
\text { compared to the } \\
\text { same period of } \\
\text { last year\% }\end{array}$ & $\begin{array}{c}\text { Total case of } \\
\text { pre-litigation } \\
\text { procedure } \\
\text { (per case) }\end{array}$ & $\begin{array}{c}\text { Number of pre- } \\
\text { litigation procedural } \\
\text { cases of } \\
\text { administrative } \\
\text { public interest } \\
\text { litigation (per case) }\end{array}$ & $\begin{array}{c}\text { Number of cases of } \\
\text { administrative } \\
\text { organizations } \\
\text { correcting illegal } \\
\text { acts or performing } \\
\text { duties }\end{array}$ & $\begin{array}{c}\text { The administrative } \\
\text { organizations corrects the } \\
\text { illegal acts in the total number } \\
\text { of cases in the pre litigation } \\
\text { procedure (excluding the cases } \\
\text { replied less than one } \\
\text { month) } \%\end{array}$ \\
\hline $\begin{array}{c}\text { Till December } \\
\text { 2015 }\end{array}$ & 501 & - & 245 & 212 & 118 & $79.73 \%$ \\
\hline Till June 2016 & 1942 & $288 \%$ & 1106 & 1047 & 814 & $88.86 \%$ \\
\hline $\begin{array}{c}\text { Till December } \\
\text { 2016 }\end{array}$ & 4378 & $125 \%$ & 3883 & 3763 & 2838 & $75.4 \%$ \\
\hline Till June 2016 & 9053 & $107 \%$ & 7903 & 7676 & 5162 & $77.14 \%$ \\
\hline $\begin{array}{c}\text { From January } \\
\text { 2018- } \\
\text { December } \\
\text { 2018 }\end{array}$ & - & 102975 & 101254 & 98419 & $97.2 \%$ \\
\hline
\end{tabular}

By analyzing and comparing the above data, some characteristics of public interest litigation in the pilot process can be seen:

First of all, in terms of the total number of cases, the growth rate is relatively fast. During the two-year pilot period, the percentage of growth is about $288 \%, 125 \%$ and $107 \%$ respectively every half year, while the number of administrative public interest litigation cases increases by $394 \%$ and $259 \%$ every half a year. It can be seen that the increase of both the total number of cases and the number of pre-litigation procedural cases of administrative public interest litigation is relatively large. Except the last data showing the growth rate of pre-litigation procedure of administrative public interest litigation is the same as the total number of cases. The other two groups of data show the growth rate of pre-litigation procedure is higher than the total number of cases, which from the other side also prove that the role of pre-litigation procedure in administrative public interest litigation cannot be underestimated. However, it is impossible to accurately estimate how much longer such a rapid uptrend could last: although the total number of cases is increasing, the cases handled in the field of public interest litigation are still very few. There are a lot of behaviors damaging the public interest in reality that have not been discovered, and with the enriching experience of the prosecutors in handling cases and the acceptance of this matter from the society, the development of public interest litigation will be carried out in a very favorable condition. From another point of view, the administrative public interest litigation is made to against the administrative organs, so there will be more or less conflicting emotions among the administrative organizations. In addition, after the reform of the supervision system, the withdrawal of the prosecutorial organization's self-investigation power will have a negative impact on the source of the clues of the 
prosecutorial organization's public interest litigation cases and whether the front-line procurators still handle cases with full energy after the pilot is completed which would also have a negative impact on carrying forward the public interest litigation [8].

Secondly, compared to the civil public interest litigation, the number of administrative public interest litigation cases is obviously more, especially in the second year after the pilot, the number of administrative public interest litigation cases has already accounted for $95.9 \%$ of the total number of public interest litigation cases. Every half year, the percentages of administrative public interest litigation in the total public interest litigation since the two-year pilot are around $76.4 \%$, $53.9 \%, 95.9 \%$ and $96.8 \%$ respectively. In 2018, it remained the same proportion, accounting for $96.1 \%$. Such result is closely related to the clear focus of the prosecutorial organizations on the administrative public interest litigation during the deployment of public interest litigation pilot work. The reason why the Supreme Procuratorates are so determined to define the work focus is to better supervise the power of public interest through prosecutorial organizations, while the supervision of the privileged rights is more exerted by the administrative organizations and the courts. Different functional distributions make the administrative public interest litigation correspond more to the positioning of the legal supervision organizations' functions [8].

Finally, the pre-litigation procedure of administrative public interest litigation plays an important role in the whole operation stage of the case. Although there is a slight fluctuation, around $80 \%$ of the administrative organizations would take the initiatives to correct illegal acts or perform their duties after having received prosecutorial suggestions during the pilot period. After the completion of the pilot, the proportion even reached $97.2 \%$. The majority of administrative public interest cases have been resolved in the pre-litigation procedure before entering the litigation procedure. It can be said that the pre-litigation procedure which should have played a supplementary role has become an institutional design as important as the litigation. Before the pilot work of public interest litigation, the impact of prosecutorial suggestions is very limited. However, after the start of the pilot work, the situation has been changed completely. As it can be seen from the above data, most administrative organizations will take the prosecutorial suggestions seriously and correct illegal administrative acts or perform their duties in time in order to avoid being sued by the prosecutorial organizations. For example, after procuratorate of Zhanhe District implemented the pre-litigation procedure to the Zhanhe Branch of Pingdingshan city Municipal Bureau of Land and Resources, the administrative organization immediately took effective measures to demolish the illegal buildings and restore the land to its original status [10]; after Rugao city procuratorate sent prosecutorial suggestions to the Environmental Protection Department of Gao city and the local government, it effectively solved the problems of water resources pollution and living environment deterioration caused by local dairy farms [11]. It seems that the prosecutorial suggestions initiated by the administrative public interest litigation are more deterrent. Most administrative organizations can seriously rectify and perform their functions based on the prosecutorial suggestions, and make up for the regulatory loopholes.

\section{The Practical DilemMa of PRE-Litigation PROCEDURE}

After the two-year pilot, the pre-litigation procedure has shown its irreplaceable advantages. It can not only solve the problems in practice efficiently, but also coordinate the relationship between the prosecutorial organization, the administrative organization and the judicial organization. However, due to the fact that the prosecutorial organization has not been carrying out administrative public interest litigation and pre-litigation procedure for a long time in China, there are still many difficulties and disputes in both its design and operation.

\section{A. The Pre-litigation Procedure Is Too General and the Operation Is Not Standardized}

Before the prosecutorial organization brings the administrative public interest litigation to the court, it should perform the pre-litigation procedure first, which has been written into the new Administrative Litigation Law. However, at this stage, neither the law nor the judicial interpretation involves the operational norms of the pre-litigation procedure, but only makes the principled regulations. There are no specific regulations on the starting conditions of the pre-litigation procedure, the model of legal documents, the way of delivery, the case deadlines, the prolongation standard, and the legal effect of the pre-litigation procedure. Although some contents of the prosecutorial suggestions were stipulated by the Work of Prosecutorial Suggestions of the People's Procuratorate (Trial Implementation) issued by the Supreme Procuratorate in 2009, the operation process of the prosecutorial suggestions still lack of feasibility and is difficult to apply [12]. This will lead to confusion in the specific operation of the prosecutions, different opinions from various regions in the handling of related cases and weakening the judicial authority. In addition, from the current operation of administrative public interest litigation point of view, the pre-litigation procedure has filtered out most administrative public interest litigation cases, and only a few cases will eventually enter the judicial trial stage. It can be said the pre-litigation procedure has now become the most important solution for the administrative public interest litigation cases, and both social public interest and national interest can be maintained through this vital procedure. Therefore, it is particularly important to issue specific laws or judicial interpretations to regulate the pre-litigation procedure of the prosecutorial organization. 


\section{B. The Definition of Judging the Administrative Organizations Failing to Perform Their Duties}

Compared with the Pilot Program, the Judicial Interpretation of Public Interest Litigation extended the reply deadline for one month after the administrative organization had received the prosecutorial suggestions, which gave the administrative organization more time to investigate the truth and correct the mistakes. However, it is still a complicated problem in reality that how the prosecutorial organization determines the duties fulfilled by the administrative organization, plus there are also different opinions between the prosecutorial and the administrative organizations. There are two kinds of illegal situations in administrative organizations: illegal with act and illegal with omission. In case the administrative organization violates the law, after the prosecutorial organization performs the pre-litigation procedure, normally the administrative organization can correct the mistakes in time, and it is easier to judge whether it performs its duties. However, it is always difficult to judge the situation of "illegal with omission" in reality. Moreover, the author found that the administrative public interest litigation brought by the omission of the administrative organization were the majority of cases, so the following content will focus on the discussion of the administrative omission [13].

In order to define the omission of administrative organization, first of all, we should judge whether they have regulatory responsibilities based on the relevant laws and regulations. However, due to the wide range of administrative acts, a person cannot avoid dealing with administrative organizations from the day he or she was born till the day he or she passes away. Currently, there are many existing administrative laws and regulations in China, which are contradictory or no existing. The division and definition of the responsibilities of administrative organizations are not comprehensive enough, which leads to regulatory loopholes in reality and clears up the applicable fields and targets of public interest litigation [15].

In addition to the judgment of the legal duties from the legal perspective, it is also necessary to judge whether the administrative organizations have performed their legal duties and there is force majeure or the performance is meaningless, which results in the impossible situation objectively. During practice, not responding to prosecutorial suggestions or not performing their duties completely is considered as omission? Is the definition of omission based on the administrative acts of the administrative organizations or the ultimate restoration of public interest? These are important issues that need to be identified and discussed in both practice and theory.

\section{The Investigation and Evidence Collection of Prosecutorial Organizations in the Pre-litigation Procedure}

The Implementation Measures of the People's Procuratorate for Issuing Public Interest Litigation (hereinafter is called "Implementation Measures") clearly stipulates several ways of investigation and evidence collection for prosecutorial organizations, including six specific measures such as selective reading and copying administrative law enforcement files etc. The last clause also points out the administrative organizations, relevant units and individuals shall cooperate with prosecutorial organizations' investigations [14]. However, the Implementation Measures is not a law and doesn't define the responsibilities of the administrative organizations when not cooperating with the investigation, thus in practice, problem of the administrative organizations not cooperating with the investigation is easy to occur. For example, some administrative organizations may perfunctory prosecutorial organizations and refuse to be investigated for the reasons of the law enforcement personnel or leaders being absent; some administrative organizations may not provide the prosecutorial organizations with files of law enforcement and so on. In addition, in some cases of environmental pollution, the cost of pollution identification is normally very high, some of which can even exceed one million RMB. For grassroots' procuratorates, it is sometimes difficult to afford, and it may also needs to apply for the local government to increase the case funds, which make it very difficult in reality [16]. All of these factors will bring obstacles to the investigation of public interest litigation cases handled by prosecutorial organizations, and bring down their enthusiasm in handling cases.

In addition, against the background of the supervision organization's reform, the self-investigation power of dutyrelated crimes and violations of the prosecutorial organizations has been integrated into the supervision committee, which makes the prosecutorial organizations face greater resistance in the process of administrative public interest litigation. Before the reform, the prosecutorial organizations had a strong deterrent power in front of other departments because of its self-investigation power. Out of the pressure, the staff of the administrative organizations will actively cooperate with the investigation and the inquiry of the prosecutorial organizations. Especially in the field of environmental pollution and resource protection, out of fear of being investigated their own duty crimes, the person in charge of the organizations may actively cooperate with the verification and investigation of the prosecutorial organizations after having received the prosecutorial advices as well as be able to take the initiatives to correct illegal administrative acts or perform their duties promptly. But after the adjustment of the duty power, the prosecutorial organization is facing a big challenge: on one hand, it is more difficult to find the clues of the case since the power of investigation is removed due to the Administrative Procedure Law limits the way of prosecutorial organizations finding clues within the process of "performing duties", and during the pilot period, most of the clues are transferred by the internal anti-corruption and anti-malfeasance departments of the prosecutorial organizations [16]; on the other hand, the evidence investigation of administrative public interest litigation cases is very difficult, and the power of self- 
investigation in duty crimes before the reform has been greatly weakened, so it's not hard to imagine the cooperation level of the administrative staff to the investigation work of the prosecutorial organizations, which makes the prosecutorial organizations in a passive status in the early stage of the case [18]. Therefore, how to expand the source of case clues and improve the ability and the power of investigation and evidence collection of the civil and administrative departments of prosecutorial organizations is an urgent problem to be solved.

\section{SUGGESTIONS ON IMPROVING THE PRE-LITIGATION PROCEDURE}

As mentioned previously, although the pre-litigation procedure has obvious advantages in public interest litigation activities and has been a successful system design, there are still some problems to be solved in reality. In order to maximize the institutional functions of the pre-litigation procedure, the author will give some suggestions on the current imperfections of the pre-litigation procedure.

\section{A. Specifying the Operational Standards of Pre-litigation Procedure}

Specifying the relevant provisions of the pre-litigation procedure can help the prosecutorial organizations exert the right of legal supervision. Therefore, it is necessary to take the form of the law or judicial interpretation to clearly define the start-up standards of pre-litigation procedure and the content of prosecutorial suggestions, establish scientific delivery manner and timing of prosecutorial suggestions, the period of prelitigation procedure and the time limit for handling cases, etc., in order to avoid the situation that the right and obligation among various power organizations not being clear, prevarication and wrangle occurring, which makes the prelitigation procedure just a formality[19]. In addition, establishing a public hearing system of pre-litigation procedure is also a good way. The public is the most direct victim of illegal administrative acts. If the opinions of the public are listened, it can not only make the operation of pre-litigation procedures more fair and transparent, but also urge the administrative organizations to accurately master the responsive level of public interests and the performance of their own functions. What's more, relevant laws should be formulated to ensure the effective implementation of prosecutorial suggestions. For example, when dealing with the case of "Stinky cattle farm", Rugao Municipal Procuratorate sent prosecutorial suggestions to the Environmental Protection Department of Rugao city and the local government, followed up and supervised the situation of cleaning and restoration three times, and finally achieved good results. Therefore, it is necessary to establish a follow-up mechanism, supervise the duty performance of administrative organizations, and decide whether to file administrative public interest litigation according to the law.

\section{B. Judgment on Whether Administrative Organizations Perform Their Duties According to the Law}

To determine whether the administrative organizations fail to perform their duties or violate the law, first of all it should be looked at based on the specific legal regulations on administrative acts in respective fields. However, in the actual situation of extensive administrative matters and incomplete regulations of relevant laws, the responsibilities and jurisdictions of different administrative organizations should be clearly defined through legislation. It's supposed to divide the boundary of power and try to avoid the supervision loopholes, but from the current legal situation of our country, it is bounded to be a difficult and long process.

In addition, in order to accurately judge whether the administrative organization has corrected the illegal administrative acts according to the law, both the act itself and the result of the act need to be examined. On one hand, it depends on whether the administrative organization has actually taken actions. Besides the documents of whether the administrative organization has issued a notice of a penalty decision or the notice to stop the illegal act to the relevant departments or individuals, it is necessary to make a constant follow-up on improving the subsequences. Because there is a process to deal with the damage of public interest, the legal party should not only stop the illegal act, but also restore the damaged public interest with the reach of a certain standard. In practice, the prosecutorial organization will return to the scenes for a follow-up investigation after having issued the prosecutorial suggestions. The administrative organization should take the initiatives to report the case results handled in each stage to the prosecutorial organization after having performed its duties, so that the prosecutorial organization get to know the recovery of public interest; On the other hand, it should also investigate whether the damaged public interest has been restored, which is the processed result of the administrative organization [20]. If the administrative organization has done administrative acts, but has not restored the damaged public interest, then the prosecutorial organization should bring the administrative public interest lawsuit to the court. For example, in the case of People's Procuratorate of Bureau of Land, Resources and Environmental Protection of Gengma Dai and Wa Autonomous County, the defendant issued a letter of decision on administrative penalty to Gengma Jinxiang cement prefabrication pipe factory after having received the suggestions of the procuratorate, but the content of the penalty was not implemented in reality, neither no effective measures were taken to urge the implementation, which has resulted in the illegal occupation of land resources. The prosecutorial organization then brought the administrative public interest lawsuit to the court.

Whether they should take not replying to the prosecutorial suggestions as the standard of defining the administrative organization's "illegal with omission", the author believes the answer should be no. The purpose of administrative public 
interest litigation is to relieve the damaged public interest, whether the administrative organization performs its duties in reality is far more important than the reply to the prosecutorial suggestion. If the administrative organization seriously replies to the prosecutorial suggestion without taking any actual actions, then it's also considered as "illegal with omission". On the contrary, if the administrative organization has performed the corresponding administrative duties but failed to respond to the prosecutorial suggestions in time due to negligence or other reasons, it should not be taken as omission. And when the prosecutorial organization files the administrative public interest litigation once more, it makes the whole process meaningless. In case that the administrative organization has performed part of its duties, but the public interest has not been fully relieved, whether to file a lawsuit should be decided by the actual situation. If the neglected part can still be performed with practical significance, and the public interest is still damaged, it's necessary to file the administrative public interest litigation.

\section{Suggestions on the Investigation and Evidence Collection of Prosecutorial Organization}

In order to improve the prosecutorial organization's ability to investigate and collect evidence in administrative public interest litigation, the author believes the most urgent thing is to coordinate the relationship between the prosecutorial organizations and the administrative organizations and reduce the mutual conflict or confrontation. In some cases, most of the evidences administrative organizations have already investigated and collected when executing the law, and some of the evidences cannot be collected afterwards. In fact, it is repetitive work to let the prosecutorial organizations investigate again, which is a waste of judicial resources and is not helpful to find out the truth and protect the public interest. The key problem is how to let the administrative organizations voluntarily hand over the evidence of administrative law enforcement. In fact, both the prosecutorial organizations and the administrative organizations are state bodies, who exert their functions and powers on behalf of the country. Both of them exist in the administrative public interest litigation for the purpose of safeguarding the public interest, and there is no antagonistic interest relationship between them. Therefore, we should strengthen the ideological education of the staff of both sides and reduce the mutual conflicts between them. The prosecutorial organizations can have direct access to the evidence materials collected by the administrative organizations, and the investigation activities of the prosecutorial organizations should be carried out against the evidence that has not been collected. In addition, when the administrative organization refuses to provide the law enforcement files, the legal responsible person in charge can be sued according the relevant laws so as to give certain psychological pressures [21].

In the cases of administrative omission that the administrative organization did not collect evidence materials, the prosecutorial organizations should be given more rights of investigation and evidence collection to ensure that it has sufficient evidence to realize its own claims in the following administrative public interest litigation.

\section{CONCLUSION}

As an important system design in the process of prosecuting public interest litigation, the pre-litigation procedure has great theoretical value on urging the administrative organizations to perform their duties in correspondence with the law and take the initiative to correct mistakes, it also helps to save judicial resources and reflect the modesty of judicial power. At the same time, as the data showed in judicial practice, the pre-litigation procedure of administrative public interest litigation plays an important role in the whole operation stage of the case, the majority of administrative public interest cases have been resolved in the pre-litigation procedure before entering the litigation procedure. However, there are still some problems to be solved in reality, and the pre-litigation procedure needs to be gradually improved in the future theoretical research and judicial practice.

\section{REFERENCES}

[1] Qimin Zhou. Study on the Pre-litigation Procedure of the Environmental Public Interest Litigation System Initiated by Prosecutorial Organization [D]. Jiangxi: Jiangxi University of Finance and Economics, 2016:16. (in Chinese)

[2] Bin Zhang, Yibo Zhang. Analysis of the Basic Theory of Pre-litigation Procedure in Administrative Public Interest Litigation [J]. People's Procuratorate, 2017-2,62 (4): 63-65. (in Chinese)

[3] Chunye Wang. Discussion on "Pre-litigation Procedure" of Administrative Public interest litigation initiated by Prosecutorial Organization[J]. Journal of Jianghan University, 2018,35 (3): 31. (in Chinese)

[4] Peidong Gu. Contemporary Judicial Ecology and Its Improvement in China [J]. Legal research, 2016, (2): 26. (in Chinese)

[5] Bo Peng. Half Year of the Pilot, the Highest Exam Report First Published by the Supreme People's Procuratorate - Public Interest Litigation: Good Practice, Propose Legislation [N]. People's Daily, 2016-01-07. (in Chinese)

[6] Ziyang Liu. In the Pilot Year, Prosecutorial Organizations Filed 30 Public Interest Lawsuits and 1942 Clues Founded [N]. Prosecutorial Daily, 2016-07-19. (in Chinese)

[7] Peng Bo. One and A Half Years after the Pilot, the Prosecution Handled 4378 cases and Filed 495 Lawsuits - Public Interest Litigation to Promote Administration According to Law [N]. People's daily, 2017-0105. (in Chinese)

[8] Ziru Yu. Two-year Public Interest Litigation Pilot, Prosecutorial Organizations Handled 9053 Cases [N]. Xinhuanet, 2017-6-30. (in Chinese)

[9] Ke Shao, Ping Lin, Yu Zhang. The Supreme People's Procuratorate: Prosecutorial Organizations Filed More Than 108,000 Administrative Public Interest Litigation Cases Last Year [N]. THE PAPER, 2019-0312. (in Chinese)

[10] Weilie Hu, Xiaoyan Chi. Pre-Litigation Procedure of Administrative Public Interest Litigation from the Perspective of the Pilot[J]. Journal of National Prosecutors College, 2017-03, 25 (2): 34. (in Chinese) 
[11] Weilie Hu, Kai Tian. Research on the Pilot Cases of Administrative Public Interest Litigation Initiated by Prosecutorial Organizations[J]. Administrative Law Review, 2017, (2): 23. (in Chinese)

[12] Lixin Liu, Qinghua Huang, Haoming Li. The Prosecution of Zhanhe in Pingdingshan Initiated the Pre-Litigation Procedure to Urge the Land And Resources Department to Dismantle the Illegal Construction in Accordance with the Law[N]. Prosecutorial Daily, 2019-3-21. (in Chinese)

[13] Zhijian Lu, Ai Hua, Yue Zou. Public Interest Litigation Solves Judicial Problems: the dairy farm with fecal pollution is finally moved [N]. Prosecutorial Daily, 2019-4-14. (in Chinese)

[14] Cuixia Xu, Xiaomei Luo, Changtai Huang. An Empirical Study on the Pre-litigation Procedure of Environmental Administrative Public Interest Litigation [J]. Journal of Jimei University (Philosophy and Social Science Edition), 2019,22 (1): 73. (in Chinese)

[15] Chunye Wang. Discussion on the "Pre-litigation Procedure" for Prosecutions to File Administrative Public Interest Litigation [J]. Journal of Jianghan University (Social Sciences Edition, 2018-06, 35 (3): 30-35. (in Chinese)

[16] Zongxiang Gao. Discussion on the Implementation of Administrative Public Interest Litigation System [J]. People's Procuratorate, 2016, 5 (10): 8. (in Chinese)

[17] Wanhua Wang. Several Issues on Improving the Public Interest Litigation System of Prosecutorial Organizations[J]. Law Science Magazine, 2018, (1): 105. (in Chinese)

[18] Yan Cai. Exploring the Ways to Find Clues in Public Interest Litigation Cases [N]. Jiangsu Economic News, 2018-7-17. (in Chinese)

[19] Baobao Ma, Feng Zhang. Research on Pre-Litigation Procedure of Environmental Public Interest Litigation [J]. Journal of Shandong University of Technology (Social Sciences Edition), 2018,34 (2): 49. (in Chinese)

[20] Chunye Wang. Inspection on the "Pre-Litigation Procedure" of Administrative Public Interest Litigation [J]. Social sciences, 2018, (6): 98-99. (in Chinese)

[21] Kaiju Shen, Xin Xing. Empirical Study on the Pre-Litigation Procedure of Administrative Public Interest Litigation Initiated by Prosecutorial Organizations [J]. Administrative law research, 2017, (5): 41-42. (in Chinese) 